\title{
First Record of Two Gobiid Fishes, Luciogobius elongatus, L. platycephalus (Perciformes: Gobiidae) from Korea
}

\author{
Hyun-Geun $\mathrm{Cho}^{1}$, Seung-Ho Choi ${ }^{2, *}$ \\ ${ }^{1}$ Animal Resources Division, National Institute of Biological Resources, \\ Environmental Research Complex, Incheon 404-708, Korea \\ ${ }^{2}$ Korean Association for Conservation of Freshwater Fish, Seoul 135-709, Korea
}

\begin{abstract}
Two species of small gobiid fishes genus Luciogobius, i.e., L. elongatus, L. platycephalus were described as the first records from Korea based on specimens collected from gravel beaches of Gijang-gun, Busan-si, Korea. Luciogobius elongatus is distinguished from congeners by very elongated and naked body, 42-44 vertebrae, 6-7 dorsal soft rays, and no free rays on pectoral fin, and L. platycephalus is characterized by having very depressed head, naked body, 40-41 vertebrae, 10-11 dorsal soft rays, and pectoral fin with only upper 2-4 free rays. We propose the new Korean name "Ga-neun-mi-kkeun-mang-dug", "Nab-jak-mi-kkeunmang-dug" for L. elongatus and L. platycephalus, respectively.
\end{abstract}

Keywords: Gobiid fishes, Luciogobius elongatus, Luciogobius platycephalus, first record, gravel beaches

\section{INTRODUCTION}

The gobiid fishes of genus Luciogobius Gill, 1859, mainly inhabit the shallow, cryptobenthic habitats of freshwater stream, estuaries, intertidal zone of coasts, and subterranean waters with the exception of Luciogobius adapel, which has been collected from the bottom of the sea at depths of $20 \mathrm{~m}$ to $50 \mathrm{~m}$ in Eastern Asiatic region including Primorsky Kray, Japan, China, Taiwan, and Korea (Okiyama, 2001; Chen et al., 2008; Maeda et al., 2008; Kanagawa et al., 2011; Kondo et al., 2012). The genus with elongated, worm-like body shape, depressed head, and absence of the first dorsal fin has been considered as comprising 16 nominal species (Kanagawa et al., 2011; Kondo et al., 2012), and of these, five species i.e., L. grandis Arai, 1970, L. guttatus Gill, 1859, L. koma (Snyder, 1909), L. saikaiensis Dôtu, 1957, and L. pallidus Regan, 1940, have been only reported from Korean waters to date (Kim, 2012).

In the course of surveys on fish fauna of intertidal zone, two unrecorded species of Luciogobius were collected from rocky coasts with round pebbles exposed to the air during low tide on the Southern Coast of Busan-si, Korea, and found that they are L. elongatus Regan, 1905, L. platycephalus
Shiogaki and Dotsu, 1976, respectively. In this study, we described these species as the first records from Korea, and represent a diagnostic key on the genus Luciogobius from Korea.

\section{MATERIALS AND METHODS}

The specimens of Luciogobius elongatus and L. platycephalus examined in the present study are deposited in National Institute Biological Resources (NIBR). All counts and measurements were made from specimens preserved in $75 \%$ ethanol. Morphometric and meristic methods generally followed Hubbs and Lagler (2004) and Akihito et al. (1984). Counts of dorsal and anal fin rays, and vertebrae were taken from a radiograph. The method of counting and the formula for the relation between the pterygiophores of the dorsal fin and vertebrae follow those of Akihito et al. (1984). Standard length and head length are expressed as SL and HL, respectively. The single dorsal fin composed of one spine and numerous soft rays was regarded as the "second dorsal fin" based on consideration of the evolutionary trends of this genus (Okiyama, 2001).

\footnotetext{
(c) This is an Open Access article distributed under the terms of the Creative Commons Attribution Non-Commercial License (http://creativecommons.org/ licenses/by-nc/3.0/) which permits unrestricted non-commercial use, distribution, and reproduction in any medium, provided the original work is properly cited.

pISSN 2234-6953 eISSN 2234-8190

*To whom correspondence should be addressed

Tel: 82-2-554-5154, Fax: 82-2-554-5172

E-mail: choifish@hanmail.net 


\section{SYSTEMATIC ACCOUNTS}

Order Perciformes Bleeker, 1859

Family Gobiidae Cuvier, 1816

Genus Luciogobius Gill, 1859

1*Luciogobius elongatus Regan, 1905 (Table 1, Fig. 1A)

Luciogobius elongatus Regan, 1905: 23 (type locality: inland sea of Japan); Shiogaki and Dotsu, 1972: 9-18; Akihito et al., 1984: 282.

Material examined. 5 specimens, 30.7-33.9 mm SL, Korea: Busan-si, Gijang-gun, Ilgwang-myeon, Sinpyeong-ri (35 $17^{\circ}$ $\left.32.78^{\prime \prime} \mathrm{N}, 129^{\circ} 15^{\prime} 39.22^{\prime \prime} \mathrm{E}\right), 4$ Apr 2011, NIBR-P13513.

Description. Comparison of counts and measurements is shown in Table 1. First dorsal fin absent; second dorsal fin rays I,6; anal fin rays I,7; pectoral fin rays 8; first dorsal pterygiophore inserted between 24th and 25th vertebrae; last dorsal pterygiophore inserted between 27 th and 28th vertebrae; total dorsal pterygiophore 7-8; vertebrae $(\mathrm{AV}+\mathrm{CV})(20-21)$ $+(22-23)=42-44$. Measurements in \% of SL: head length 13.2-14.9 (mean 14.0); body depth 5.3-7.2 (6.1); predorsal length 68.1-70.5 (68.9); preanal length 61.4-66.2 (63.4); dorsal fin base 6.6-8.5 (7.3); anal fin base 9.5-11.0 (10.3); caudal peduncle length 21.1-27.4 (24.8); caudal peduncle depth 4.4-6.2 (5.0). Measurements in \% of HL: snout length 19.0-35.4 (25.5); eye diameter 6.4-12.5 (8.4); interorbital width 16.7-23.8 (19.6).

Body very elongated and naked, cylindrical anteriorly and somewhat compressed posteriorly. Head small. Mouth terminal; maxilla extending to posterior margin of eye. Teeth on both jaws with 3-4 rows of tiny conical teeth. Tongue deeply notched to middle part. Eyes moderately small and located front than center of head. Snout flat and short. Two paired nasal pores on dorsal part between upper lip and eyes. Anterior nasal pores as a protruded, horizontal short tube; reaching to tip of snout, and posterior nasal pores as a round hole; it located closer to eyes than upper lip. Interorbital region flat. First dorsal fin absent. Origin of second dorsal fin in front of that of anal fin. Pectoral fin rounded and small. Pelvic fin very small sucker form. Caudal fin small and circular. Cephalic lateral line system. Sensory canal and pore absent. Sensory papillae scattered, arranged some longitudinal rows on occipital region, cheek, and opercle.

Coloration when fresh. Based on the fresh specimens from Gijang-gun, Busan-si (Fig. 1), the body and head light brown to yellowish brown background. All fins white with many light brown spots.
Ecological notes. This small, elongate gobiid fish growing to a maximum of $40 \mathrm{~mm}$ inhabits a pebbled surface area in an upper intertidal zone, and it burrowed among moistened pebbles during ebb tide (Shiogaki and Dotsu, 1972; present study).

Distribution. Although the present specimens have been only obtained from Gijang-gun, Busan, Korea, the species is also found on the southern coast of Korea including Geoje Island and Jeju island (personal observation). Known from Amori pref. to Okinawa islands in Japan (Akihito et al., 1984, 2002).

Remarks. During the survey of fish fauna in a intertidal region on the Southern Coast of Korea, we collected 5 species of small fishes belonging to Luciogobius, including L. guttatus Gill, 1859, L. grandis Arai, 1970, L. saikaiensis Dôtu, 1957, and two unrecorded species from Korea. One of these species had a very elongated body shape and was identified as L. elongatus, because all morphological characters corresponded with the original description by Regan (1905) as well as subsequent descriptions of the species given by Shiogaki and Dotsu (1976), Akihito et al. (1984), and Chen et al. (2008).

According to Chen et al. (2008), L. elongatus with its naked body, more than 40 total vertebrae, and anal fin origin in front of dorsal fin origin, shares the same morphological features as the following four species: L. guttatus Gill, 1859, L. parvulus (Snyder, 1909), L. grandis Arai, 1970, and L. platycephalus, Shiogaki and Dotsu, 1976. However, L. elongatus was easily distinguishable from the others by a very elongated body, 6 dorsal soft rays, and no free soft rays on pectoral fin.

\footnotetext{
${ }^{2 *}$ Luciogobius platycephalus Shiogaki and Dotsu, 1976 (Table 1, Fig. 1B)

Luciogobius platycephalus Shiogaki and Dotsu, 1976: 126 (type locality: intertidal zone on the coast of Kawahara, Sanwa-cho, Nakasaki, Japan); Shiogaki and Dotsu, 1977: 43-48; Akihito et al., 1984: 282.
}

Material examined. 2 specimens, 44.5-53.8 mm SL, Korea: Busan-si, Gijang-gun, Ilgwang-myeon, Sinpyeong-ri (35 $17^{\prime}$ $\left.32.78^{\prime \prime} \mathrm{N}, 129^{\circ} 15^{\prime} 39.22^{\prime \prime} \mathrm{E}\right), 6$ Apr 2011, NIBR-P13514; 3 specimens, 41.6-55.3 mm SL, Busan-si, Gijang-gun, Ilgwang-myeon, Sinpyeong-ri ( $35^{\circ} 17^{\prime} 32.78^{\prime \prime} \mathrm{N}, 129^{\circ} 15^{\prime} 39.22^{\prime \prime}$ E), 4 Apr 2011, NIBR-P13515.

Description. Comparison of counts and measurements is shown in Table 1. First dorsal fin absent; second dorsal fin rays I, 10; anal fin rays I, 12-13; pectoral fin rays 13-15; pelvic fin rays I, 5; first dorsal pterygiophore just reaching

Korean name: ${ }^{1 *}$ 가는미끈망둑 (신칭), ${ }^{2 *}$ 납작미끈망둑 (신칭) 
Table 1. Comparison of counts and measurements of Luciogobius elongatus and L. platycephalus

\begin{tabular}{|c|c|c|c|c|c|c|}
\hline & \multicolumn{3}{|c|}{ L. elongatus } & \multicolumn{3}{|c|}{ L. platycephalus } \\
\hline & $\begin{array}{c}\text { Present } \\
\text { specimens }\end{array}$ & $\begin{array}{l}\text { Regan } \\
(1905)\end{array}$ & $\begin{array}{l}\text { Akihito } \\
\text { et al. } \\
(1984)\end{array}$ & $\begin{array}{c}\text { Present } \\
\text { specimens }\end{array}$ & $\begin{array}{c}\text { Holotype and } \\
\text { paratypes } \\
\text { (Shiogaki and } \\
\text { Dotsu, 1976) }\end{array}$ & $\begin{array}{c}\text { Akihito et al. } \\
(1984)\end{array}$ \\
\hline Standard length (mm) & $31.7-33.9(n=5)$ & 40.0 & 38.0 & $42.1-54.8(n=6)$ & $70.9-82.3(n=37)$ & 55.0 \\
\hline Dorsal fin rays & $I, 6-7$ & 7 & I, 6 & $\mathrm{I}, 10-11$ & $10-13$ & I, 10 \\
\hline Anal fin rays & $\mathrm{I}, 7-8$ & 9 & I, 7 & I, $12-14$ & $13-15$ & $\mathrm{I}, 14$ \\
\hline Pectoral fin rays & $6-8$ & - & 8 & $13-15$ & $13-15$ & 14 \\
\hline Pelvic fin rays & $\mathrm{I}, 2$ & - & I, 2 & I, 5 & I, 5 & I, 5 \\
\hline Free rays on pectoral fin & Absent & - & Absent & 3-4 (upper) & $2-4$ (upper) & $2-4$ (upper) \\
\hline Vertebrae $(\mathrm{AV}+\mathrm{CV})$ & $(20-21)+(22-23)=42-44$ & - & $20+22=42$ & $17+(23-24)=40-41$ & $(16-17)+(23-25)=39-42$ & $17+24=41$ \\
\hline
\end{tabular}
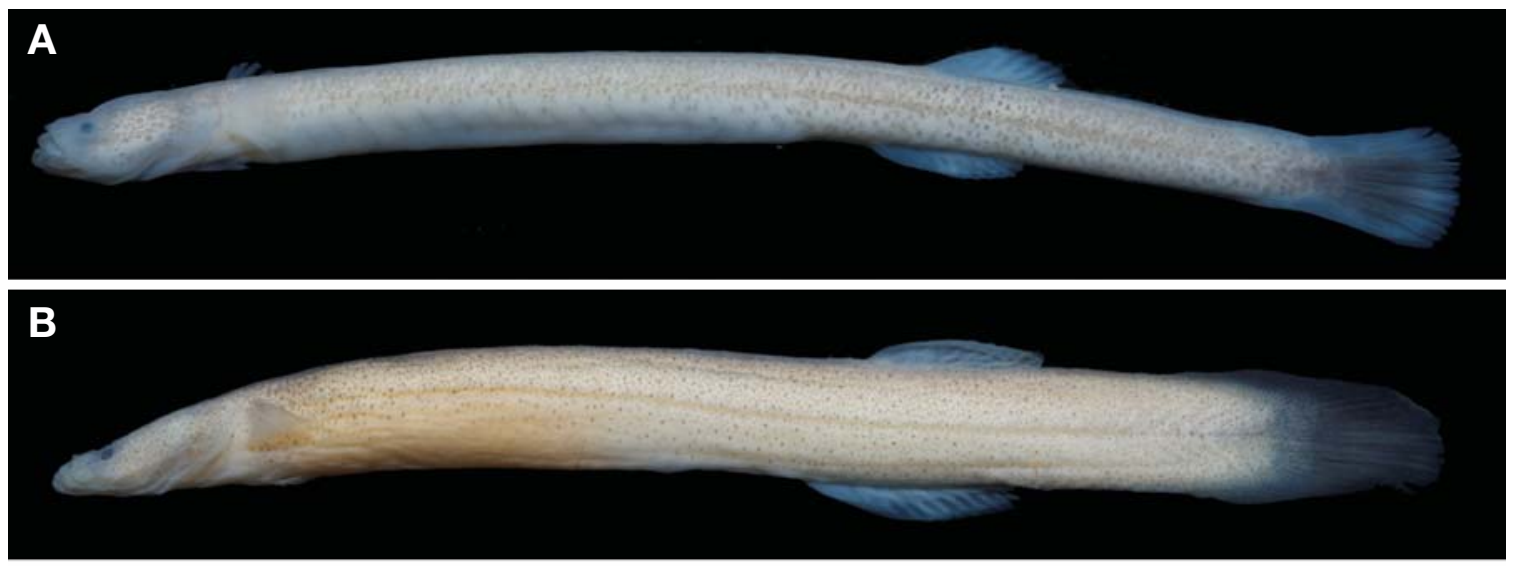

Fig. 1. A, Luciogobius elongatus (NIBR-P13513, $32.8 \mathrm{~mm}$ standard length [SL]); B, Luciogobius platycephalus (NIBR-P13514, 44.5 $\mathrm{mm} \mathrm{SL}$ ) collected from the Gijang-gun, Busan, Korea.

neural spine of 23rd vertebra or inserted between $22 \mathrm{nd}$ and 23rd vertebrae; last dorsal pterygiophore inserted between 28th and 29th vertebrae; total dorsal pterygiophore 10-12; vertebrae $(\mathrm{AV}+\mathrm{CV}) 17+23-24=40-41$. Measurements in $\%$ of SL: head length 15.6-16.2 (mean 15.9); body depth $7.5-8.9$ (8.1); predorsal length 64.7-66.3 (65.9); preanal length 59.3-61.7 (61.0); dorsal fin base 10.8-14.4 (12.4); anal fin base 16.3-18.2 (16.6); caudal peduncle length 21.9 -23.6 (23.4); caudal peduncle depth 7.7-9.0 (8.4). Measurements in \% of HL: snout length 26.4-32.8 (29.5); eye diameter 5.7-8.8 (7.2); interorbital width 20.7-23.9(21.6).

Body slender, gradually compressed posteriorly. Head very depressed and broader than body. Mouth terminal; maxilla extending below posterior margin of eye. Teeth on both jaws villiform. Tongue deeply notched to middle part. Eyes small. Snout flat and short. Nostrils separated; anterior nasal pores with a protruded, horizontal short tube above upper lip; posterior nasal pores with a round hole located center between upper lip and eyes. Interorbital region flat and moderate. Gill opening narrow, and reaching to just below lower part of pectoral fin. First dorsal fin absent. Dorsal and anal fins short and low. Origin of dorsal fin in advance of origin of anal fin. Pectoral fin with only upper 3-4 free rays rounded. Pelvic fin a small sucker form with connecting membrane. Caudal fin small fan shape.

Cephalic lateral line system. Sensory canal and pore absent. Sensory papillae scattered, arranged some longitudinal rows on occipital region, cheek, and opercle.

Coloration when fresh. Body and head light brown. Pectoral, pelvic, dorsal, and anal fins white color. Caudal fin yellowish brown.

Ecological notes. The habitats of this species growing to 80 $\mathrm{mm}$ total length is restricted to the upper intertidal zone where pebbles and stones are sedimented over the hollows of the rocky bottom, and the bottom is exposed to the air for several hours during the ebb tide (Shiogaki and Dotsu, 1977; present study). Although the present species is found from the same site as L. elongatus, the former is collected in more lower intertidal zone than the latter.

Distribution. Known from Gijang-gun of Busan-si, Geoje- 
Island, and Jeju Island, Korea (in this study; personal observation); Aomori Pref., Chiba Pref., Ehime Pref., Kochi Pref., Nagasaki Pref., Japan (Akihito et al. 1984, 2002).

Remarks. In conclusion, we identified the present specimens collected among gravels, as L. platycephalus Shiogaki and Dotsu, 1976, due to its morphological characters corresponding with the description on the species presented by Shiogaki and Dotsu (1976), Akihito et al. (1984), Chen et al. (2008), and Kanagawa et al. (2011).

Luciogobius platycephalus is easily differentiated from its most similar species, L. guttatus and L. grandis by having a very depressed snout, pectoral fin with only upper 3-4 free rays, 10-11 dorsal soft rays, and 40-41 total vertebrae.

\section{Diagnostic key for 7 species of the genus Luciogobius reported from Korea}

1. Body at least with scales on caudal peduncle ....... koma

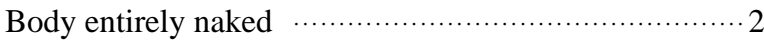

2. Dermal ridge on cheek with barbels …........ saikaiensis Dermal ridge on cheek no barbells …................... 3

3. Eyes small and embedded beneath skin; D2 origin in front of A origin ................................ pallidus Eyes moderate and not embedded; A origin in front of D2

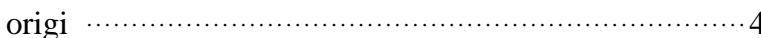

4. D2 usually 6 soft rays; $P$ in lacking any upper free soft ray elongatus

D2 more than 10 soft rays; $P$ at least with 1 or more upper free soft rays 5

5. 1 free soft ray near upper basal origin of $\mathrm{P} \cdots \cdots$ guttatus $2-5$ free soft rays on upper margin of $P \ldots \ldots \ldots \ldots \ldots \ldots 6$

6. P with 2-3 free soft rays on lower margin; D2 15 soft rays .

$\mathrm{P}$ in lacking free rays on lower margin; D2 10-11 soft rays platycephalus

\section{REFERENCES}

Akihito P, Hayashi M, Youshino T, 1984. Suborder Gobioidei. In: The fishes of the Japanese Archipelago (Eds., Masuda H, Amaoka K, Araga C, Uyeno T, Yoshino T). Tokai Univer- sity Press, Tokyo, pp. 236-289.

Akihito P, Sakamoto K, Ikeda Y, Sugiyama K, 2002. Gobioidei. In: Fishes of Japan with pictorial keys to the species (Ed., Nakabo T). English ed. Tokai University Press, Tokyo, pp. 1139-1310.

Chen IS, Suzuki T, Senou H, 2008. A new species of gobiid fish, Luciogobius from Ryukyus, Japan (Teleostei: Gobiidae). Journal of Marine Science and Technology, 16:250-254.

Hubbs CL, Lagler KF, 2004. Fishes of the Great Lake region. University of Michigan Press, Ann Arbor, MI, pp. 1-332.

Kanagawa N, Itai T, Senou H, 2011. Two new species of freshwater gobies of the genus Luciogobius (Perciformes: Gobiidae) from Japan. Bulletin of the Kanagawa Prefecture Museum (Natural Science), 40:67-74.

Kim BJ, 2012. New record of a rare hypogean gobiid, Luciogobius pallidus from Jeju Island, Korea. Korean Journal of Ichthyology, 24:306-310.

Kondo M, Maeda K, Yamasaki N, Tachihara K, 2012. Spawning habitat and early development of Luciogobius ryukyuensis (Gobiidae). Environment Biology of Fishes, 95:291-300.

Maeda K, Yamasaki N, Kondo M, Tachihara K, 2008. Occurrence and morphology of larvae and juveniles from six $\mathrm{Luc}$ iogobius species from Aritsu Beach, Okinawa Island. Ichthyological Research, 55:162-174.

Okiyama M, 2001. Luciogobius adapel, a new species of gobiid fish from Japan. Bulletin of the National Science Museum, Tokyo, 27:141-149.

Regan CT, 1905. On a collection of fishes from the inland sea of Japan made by Mr. R. Gordon Smith. Annals and Magazine of Natural History, 15:17-26.

Shiogaki M, Dotsu Y, 1972. The life history of the gobiid fish, Luciogobius elongatus. Bulletin of the Faculty of Fisheries, Nagasaki University, 34:9-18 (in Japanese).

Shiogaki M, Dotsu Y, 1976. Two new species of the genus Luciogobius (family Gobiidae) from Japan. Japanese Journal of Ichthyology, 23:125-129.

Shiogaki M, Dotsu Y, 1977. The life history of the gobiid fish, Luciogobius platycephalus. Japanese Journal of Ichthyology, 24:43-48 (in Japanese). 